\title{
Patterns of Leydig cell and LH gonadotroph activity, and plasma testosterone concentrations in the seasonally reproducing Schreibers' long-fingered bat (Miniopterus schreibersii)
}

\author{
R. T. F. Bernard*, C. Bojarski* and R. P. Millar† \\ *Department of Zoology \& Entomology, Rhodes University, Grahamstown 6140 South Africa; and \\ $\dagger M R C$ Regulatory Peptides Research Unit, Department of Chemical Pathology, \\ University of Cape Town, Medical School, Observatory 7925, South Africa
}

\begin{abstract}
Summary. Spermatogenesis in Schreibers' long-fingered bat from $\sim 33^{\circ} \mathrm{S}$ in South Africa was seasonal, and occurred in the 3 months (February-April) preceding ovulation. The ultrastructure of the Leydig cells indicated a period of increased steroidogenesis at this time, and plasma testosterone concentrations were elevated from March to May $(10.3 \mathrm{ng} / \mathrm{ml})$. The reproductive accessory glands were secretorily active between March and May, and copulation occurred at the end of this period of activity. Changes in LH- $\beta$ immunoreactivity suggest that the LH gonadotrophs were secretorily active 1 month before the onset of spermatogenesis and that peak activity coincided with peak plasma testosterone concentrations, spermiogenesis and spermiation. During winter (May-August) there was no reproductive activity and the bats remained active, only entering prolonged periods of torpor during particularly cold spells. A secondary elevation in plasma testosterone concentration, during reproductive inactivity (October; $9.3 \mathrm{ng} / \mathrm{ml}$ ), was not accompanied by any change in Leydig cell ultrastructure, and the biological significance of this peak is unknown. Such synchronous activity of the pituitary, Leydig cells, seminiferous epithelium and accessory glands is associated with the typical reproductive cycle of long-fingered bats in which copulation and fertilization are restricted to a brief period at the end of summer, and in which neither sperm storage nor a prolonged period of copulation occur.
\end{abstract}

Keywords: plasma testosterone; Leydig cell ultrastructure; gonadotroph activity; bat

\section{Introduction}

The reproductive cycle of most hibernating vespertilionid male bats is characterized by spermatogenesis in summer with initial copulation at the onset of winter. During winter there is no spermatogenic activity but spermatozoa are stored in the cauda epididymidis, the accessory glands remain active, and further copulations may occur (Gustafson, 1979; Racey, 1982, for reviews). The reproductive cycle of male long-fingered bats of the genus Miniopterus differs from this pattern and although spermatogenesis occurs in summer with copulation before winter, both the seminiferous tubules and accessory glands regress and are inactive in winter (Richardson, 1977; Racey, 1982; van der Merwe, 1986). Studies of the control of male reproductive processes have shown that the winter activity of the accessory glands and continued libido may be associated with either Leydig cell activity and high testosterone concentrations (Racey \& Tam, 1974, for the pipistrelle, Pipistrellus pipistrellus) or with inactive Leydig cells and low plasma testosterone concentrations (Gustafson, 1979, 1987, for the little brown bat, Myotis lucifugus). While morphological and histological studies 

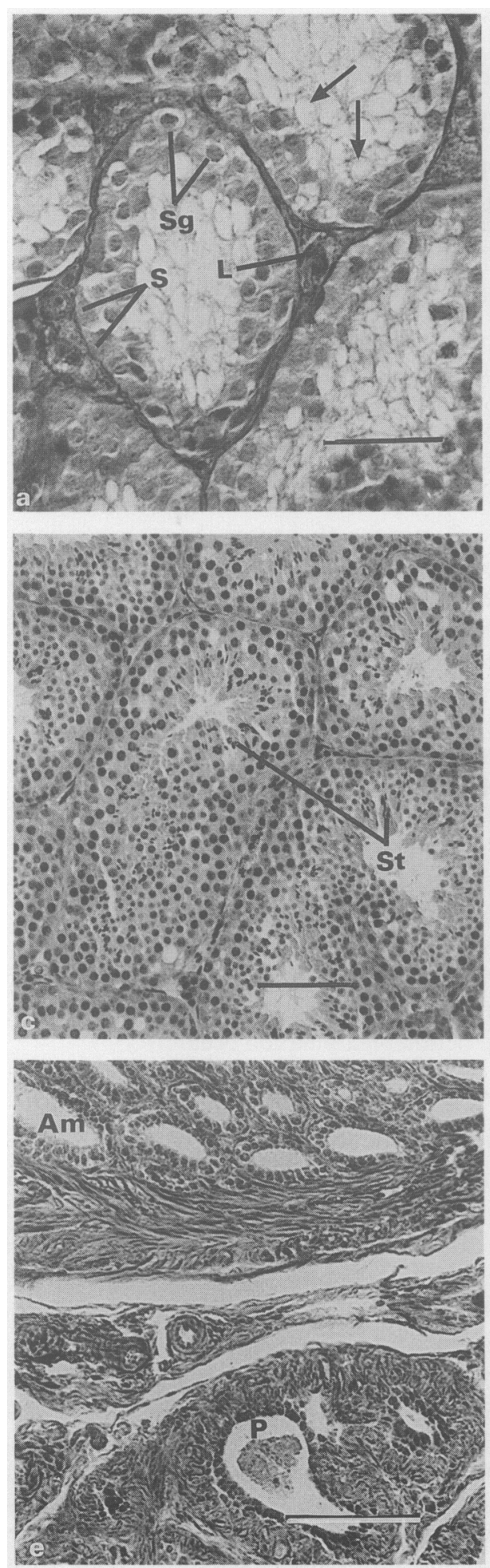
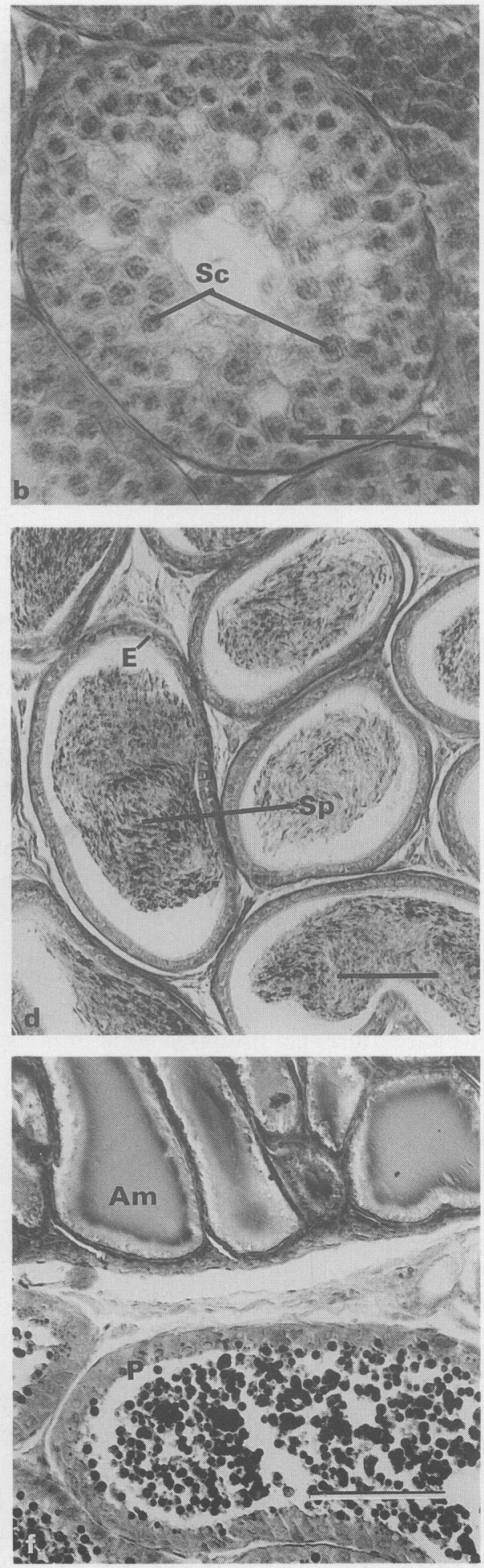


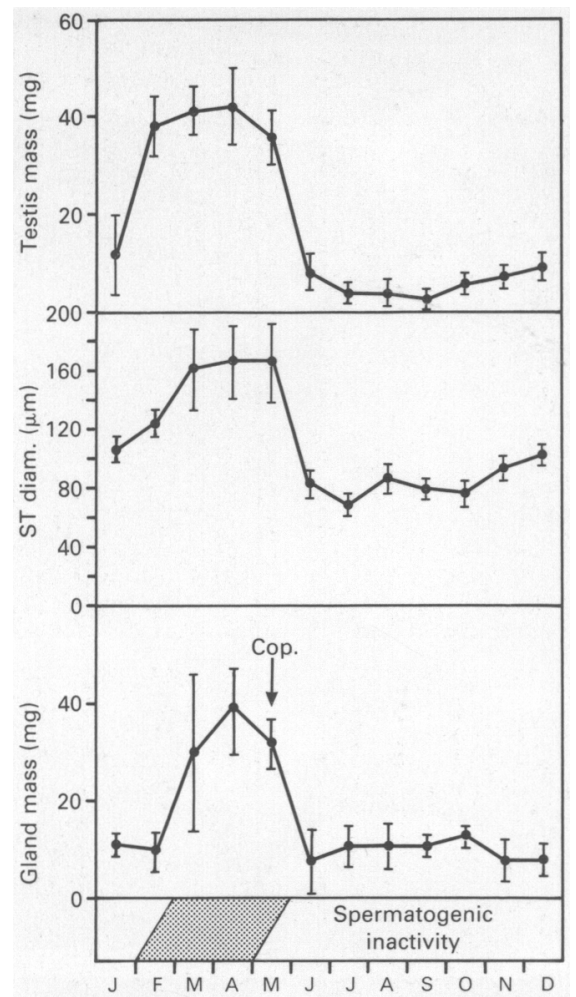

Fig. 2. Monthly changes in the mass of the testes, diameter of the seminiferous tubules (ST), and mass of the reproductive accessory glands. Values are means \pm 1 s.d. for 4 adult males per month. Shaded area represents the period of spermatogenesis. Cop. = copulation.

have established the seasonal and synchronous nature of reproduction in male long-fingered bats (McWilliam, 1988, for review), the activity of the Leydig cells and plasma testosterone concentrations have not been reported.

The role of the gonadotrophs in the control of male reproductive processes has been established for mammals in general (de Kretser, 1984; Hall, 1988, for reviews) and the limited data for bats indicate that activity of the gonadotrophs coincides with spermatogenesis (Racey, 1974; Anthony \& Gustafson, 1984; Anthony, 1987).

In this paper we describe the seasonal nature of male reproductive activity in Schreibers' longfingered bat, correlate this with plasma testosterone concentrations and with changing Leydig cell ultrastructure and assumed steroidogenic activity, and report on the seasonal activity of the LH gonadotrophs of the anterior pituitary.

Fig. 1. Light micrographs of sections through the testes and accessory glands of Schreibers' long-fingered bat. Note the typical appearance of the seminiferous tubules during reproductive inactivity (August, a), early spermatogenesis (March, b), and spermiogenesis (April, c), the cauda epididymidis during spermiation (early May, d), and the accessory glands during reproductive inactivity (e), and during spermatogenesis (f). Am = ampullary gland; $\mathrm{E}=$ epithelium of epididymis; $\mathbf{L}=$ Leydig cells; $\mathrm{P}=$ prostate gland; $\mathrm{S}=$ Sertoli cells; $\mathrm{Sc}=$ spermatocytes; $\mathrm{Sg}=$ spermatogonia; $\mathrm{Sp}=$ spermatozoa; $\mathrm{St}=$ spermatids. Arrows in (a) indicate storage droplets in the Sertoli cells. Scale bars $=50 \mu \mathrm{m}(\mathrm{a}, \mathrm{b}, \mathrm{e}, \mathrm{f}) ; 100 \mu \mathrm{m}(\mathrm{c}, \mathrm{d})$. 

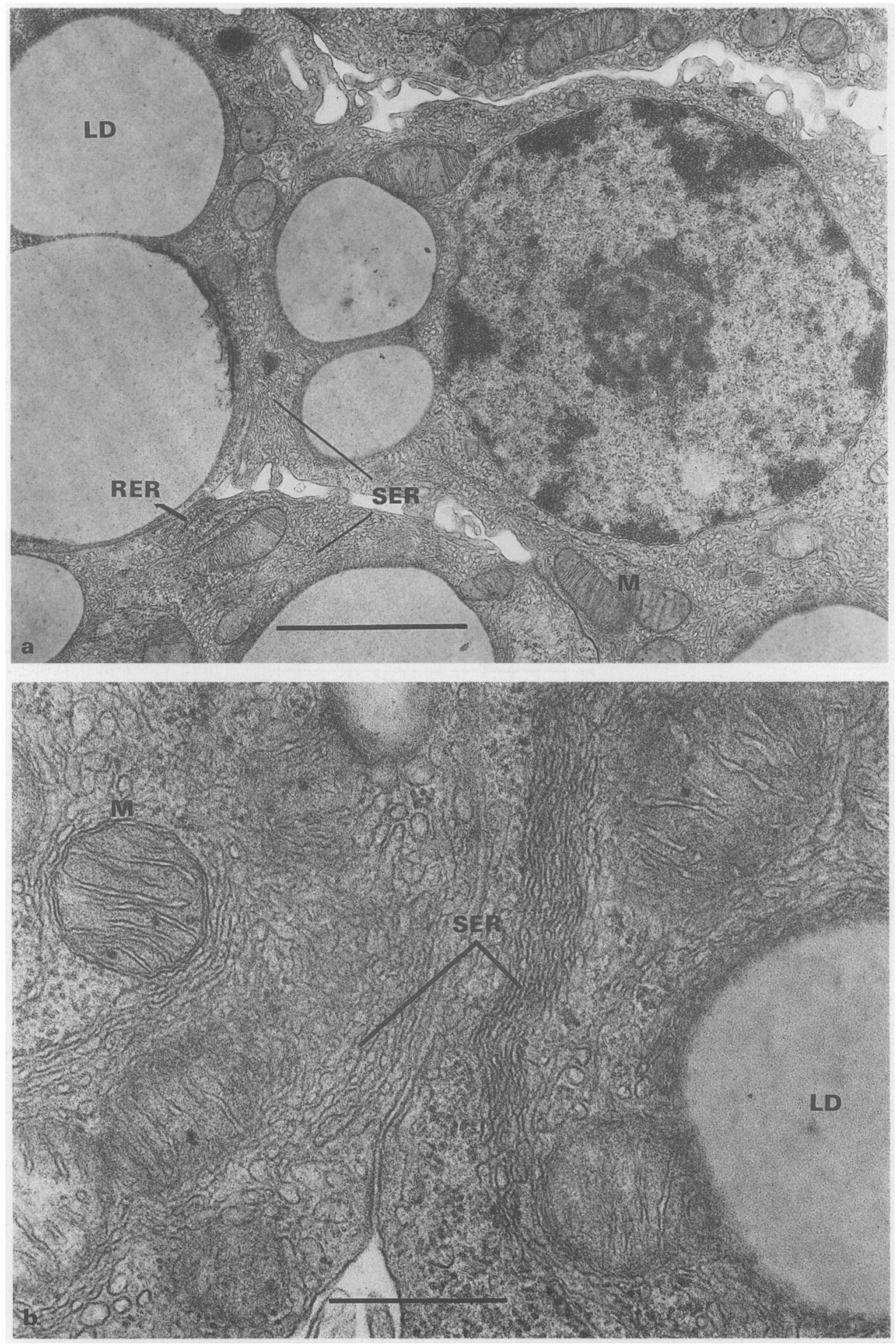
Table 1. Leydig cell size and the relative volume densities of steroidogenic organelles from spermatogenically active and inactive long-fingered bats

\begin{tabular}{|c|c|c|c|c|c|c|c|}
\hline \multirow{2}{*}{$\begin{array}{l}\text { Reproductive } \\
\text { condition } \\
\text { (months) }\end{array}$} & \multirow{2}{*}{$\begin{array}{l}\text { Leydig cell } \\
\text { diam. } \\
(\mu \mathrm{m})\end{array}$} & \multicolumn{5}{|c|}{ Relative volume densities (\% of cytoplasm) } & \multirow[b]{2}{*}{$\mathbf{N}$} \\
\hline & & Mi & & $\mathrm{Ld}$ & SER & Go & \\
\hline $\begin{array}{l}\text { Spermatogenic } \\
\text { inactivity } \\
\text { (June-January) }\end{array}$ & $\begin{array}{l}5 \cdot 2 \pm 1 \cdot 3^{\mathrm{a}} \\
(\mathrm{N}=32)\end{array}$ & $12 \cdot 7 \pm 2 \cdot 5^{2}$ & & $7 \cdot 2 \pm 1 \cdot 7^{a}$ & $67 \cdot 9 \pm 6 \cdot 3^{a}$ & $0.59 \pm 0 \cdot 11^{\mathrm{a}}$ & 19 \\
\hline $\begin{array}{l}\text { Spermatogenesis } \\
\text { (February-May) }\end{array}$ & $\begin{array}{c}9 \cdot 4 \pm 3.4^{b} \\
(\mathrm{~N}=16)\end{array}$ & $60 \cdot 1 \pm 10 \cdot 5^{b}$ & $\begin{array}{l}\text { (Feb) } \\
\text { (May) }\end{array}$ & $\begin{array}{l}51.5 \pm 24.9^{b} \\
26.7 \pm 4.0^{c}\end{array}$ & $213 \cdot 8 \pm 13 \cdot 0^{b}$ & $13 \cdot 3 \pm 0 \cdot 6^{b}$ & 13 \\
\hline
\end{tabular}

Values are mean \pm 1 s.d. for the no. of specimens indicated $(\mathrm{N}) . \mathrm{Mi}=$ mitochondria; $\mathrm{Ld}=$ lipid droplets; $\mathrm{SER}=$ smooth endoplasmic reticulum; Go = Golgi bodies. The volume density of lipid droplets is given separately for early (February) and late (May) spermatogenesis because the change in lipid droplet diameter at this time influences the measure of volume density. For each column, values with a common superscript do not differ significantly $(P>0 \cdot 05)$.

\section{Materials and Methods}

Animals. Two to three adult male specimens of Schreibers' long-fingered bat (Miniopterus schreibersii) were collected on a monthly basis from 1986 to 1989 from a set of disused mine tunnels in the East Cape region of South Africa $\left(33^{\circ} 58^{\prime} \mathrm{S}, 25^{\circ} 17^{\prime} \mathrm{E}\right)$. Winters in the study area (May to August/September) are cool and dry, and summers warm to hot and wet or dry. Bats with a body mass greater than $9.0 \mathrm{~g}$, a forearm length longer than $45 \mathrm{~mm}$, and with blunted teeth were assumed to be adult.

Specimens from 1986 and 1987 were killed by asphyxiation with $\mathrm{CO}_{2}$ and the testes, epididymides, and accessory gland complex immediately removed, weighed to the nerest $1.0 \mathrm{mg}$, and prepared for light or electron microscopy. Blood was taken from all specimens collected between January 1986 and March 1987, and in October 1987. Four juvenile males were collected in April and May 1987 and the testes prepared for light microscopy. Plasma was collected from 3 juvenile specimens in March and July.

Standard light microscopy. Tissues were fixed in buffered neutral formalin, embedded in Paraplast, sectioned at $5 \mu \mathrm{m}$, and stained with Ehrlich's haematoxylin and eosin or Mallory's trichrome.

Standard electron microscopy. Immediately after removal, the testes were decapsulated under fixative $(2.5 \%$ glutaraldehyde in $0.1 \mathrm{M}$-phosphate buffer $\mathrm{pH} 7.3)$ and cut into small pieces $\left(0.1-0.2 \mathrm{~mm}^{3}\right)$ which were fixed by immersion in the same fixative at $3^{\circ} \mathrm{C}$ for $4 \mathrm{~h}$. The tissues were secondarily fixed in $1 \%$ osmium tetroxide for $90 \mathrm{~min}$, dehydrated through an alcohol sequence and embedded in an Araldite CY212/Taab 812 resin mixture (Cross, 1989). Ultrathin sections were stained with aqueous uranyl acetate and lead citrate, and examined using a Jeol JEM 100CXII transmission electron microscope.

To optimize fixation, $2 \cdot 5,3.5$ and $5 \%$ glutaraldehyde (in $0 \cdot 1 \mathrm{M}$-phosphate buffer at $\mathrm{pH} 7 \cdot 3$ ) were used for between 1 and $12 \mathrm{~h}$. The protocol outlined above resulted in the least cell damage (cell swelling or shrinkage and mitochondrial disruption).

Immunocytochemistry. Specimens from 1988 and 1989 were killed by asphyxiation with $\mathrm{CO}_{2}$ and decapitated. To ensure rapid fixation of the pituitary gland, $10 \%$ neutral buffered formalin or $0.1 \%$ glutaraldehyde and $3 \%$ formaldehyde solution (for light and electron microscopy respectively) was injected into the brain through the foramen magnum. The pituitary gland was then removed and weighed to the nearest $0.05 \mathrm{mg}$. For light microscopy, the pituitary glands were fixed in $10 \%$ phosphate-buffered $(\mathrm{pH} \mathrm{7.3)} \mathrm{formalin} \mathrm{for} 2 \mathrm{~h}$, dehydrated and embedded in paraffin wax (solidification point of $46-48^{\circ} \mathrm{C}$ ) at a temperature of $57^{\circ} \mathrm{C}$. Sections were cut at $5 \mu \mathrm{m}$ and stained with a monoclonal bovine LH- $\beta$ antibody (dilution: 1/200; Serotec, Kidlington, Oxford, UK), an IgG-conjugated 1-nm colloidal gold probe (dilution: 1/40; Janssen, Lammerdines, Olen, Belgium) and silver enhancement (IntenSEM kit, Janssen). For electron microscopy, the pars nervosa and pars intermedia were discarded and the pars distalis fixed in $0.1 \%$ glutaraldehyde and $3 \%$ formaldehyde for $2 \mathrm{~h}$. After dehydration the tissue was embedded in resin (Cross, 1989)

Fig. 3. Electron micrographs of Leydig cells from specimens collected in February (early spermatogenesis) showing the characteristically very large lipid droplets (LD), abundant smooth endoplasmic reticulum (SER), and mitochondria (M). RER = rough endoplasmic reticulum (a). At higher magnification (b) the tubular nature of the SER is apparent. Scale bars $=2 \mu \mathrm{m}(\mathrm{a}) ; 0.5 \mu \mathrm{m}(\mathrm{b})$. 

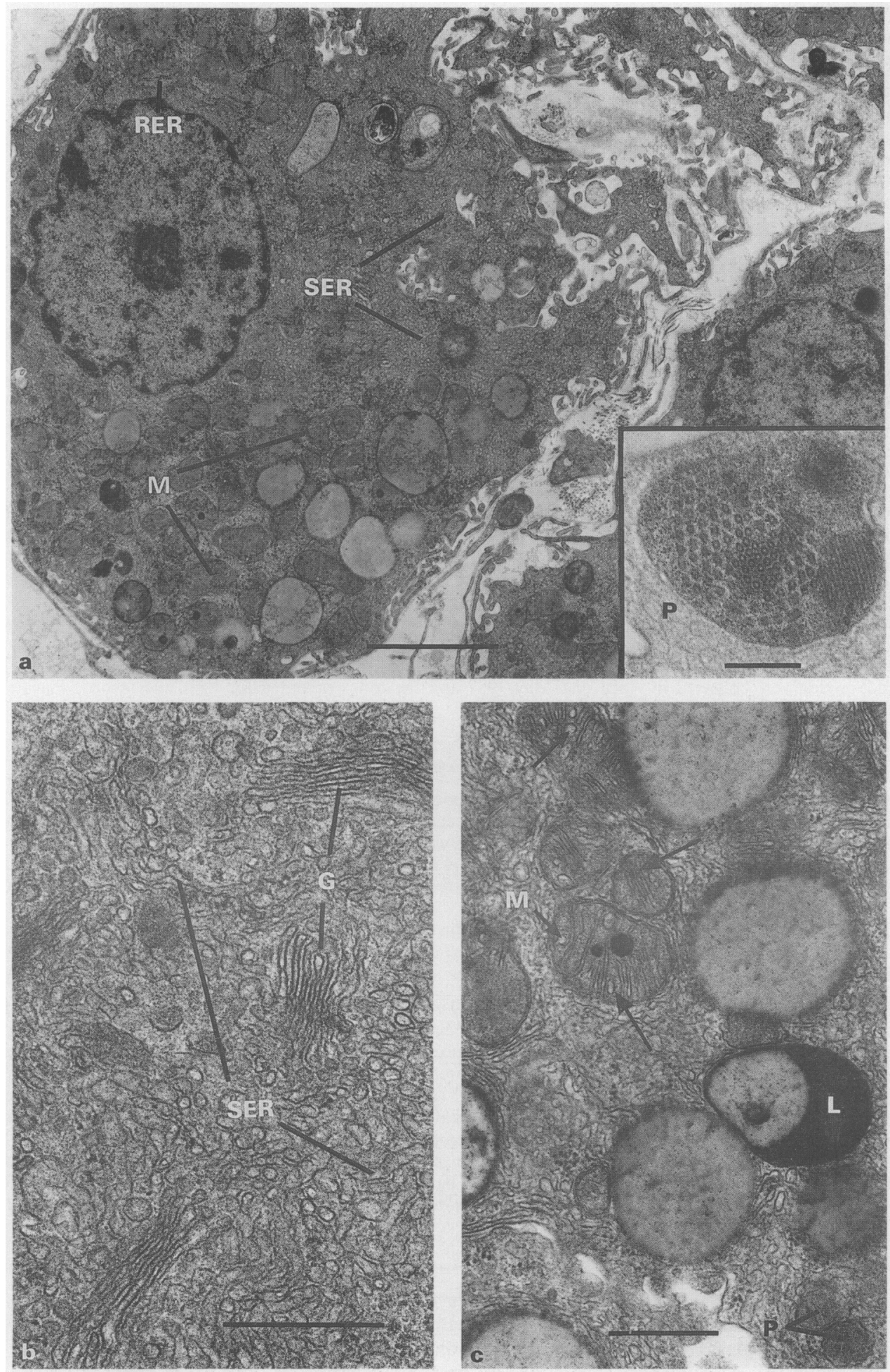
and the blocks were polymerized at $37^{\circ} \mathrm{C}$ for 10 days. Ultrathin sections were stained using a monoclonal bovine LH- $\beta$ antibody (dilution: 1/400; Serotec) and an IgG-conjugated 20 -nm gold probe (dilution: 1/40; Janssen). The sections were counterstained with $2 \%$ methanolic uranyl acetate for $5 \mathrm{~min}$, and viewed with a Jeol JEM 100CXII transmission electron microscope. Control and specificity tests were performed using standard procedures.

Quantification. Changes in the diameter of the seminiferous tubules were quantified by measuring two diameters at right angles, in cross-sections of 20 tubules from 4 specimens per month. The diameters of 10 Leydig cells, from the same 4 bats, were measured to the nearest $0.1 \mu \mathrm{m}$ using an eye-piece micrometer and light microscope at a magnification of 1000 times.

The abundance (volume density) of mitochondria, lipid droplets, Golgi bodies and smooth endoplasmic reticulum was calculated using the point-count method of Weibel \& Bolender (1973). A grid, containing 99 squares, each $9 \mathrm{~mm}^{2}$, was drawn on the screen of the electron microscope onto which the image of the tissue was superimposed. Ten Leydig cells, from 2-4 specimens each month, were selected at low power $(\times 4200)$, and the area of cytoplasm that appeared after the magnification had been increased to $\times 19000$ was used for the calculations of abundance (Crichton et al., 1989). Data from June-January (spermatogenic inactivity) and February-May (spermatogenesis) were pooled, and the morphometric analysis compares values from these two periods. Volume density does not take into account changes in the size of the Leydig cells, and to obtain a value that is relative to cytoplasmic volume, relative volume densities were calculated (Crichton et al., 1989).

The abundance of LH gonadotrophs was estimated from one mid-sagittal, immunogold-stained light-microscope section of each pituitary gland per month. The areas of the whole pituitary and positively stained gonadotrophs were measured using a digitizer tablet and the Sigma Scan software package (Jandel Scientific, Corte Madera, CA, USA). The area occupied by LH gonadotrophs was expressed as a percentage of the total area of the pituitary, and was taken as an indication of the abundance of gonadotrophs. The volume density of positively stained secretory granules in the cytoplasm of $10 \mathrm{LH}$ gonadotrophs from each pituitary was estimated using the point count technique previously described. Changes in LH- $\beta$ immunoreactivity were assessed by counting the number of gold probes on 25 granules in $10 \mathrm{LH}$ gonadotrophs for each pituitary gland during the year. Changes in the abundance of gold probes are taken as a measurement of changes in pituitary LH content (Posthuma et al., 1987).

Testosterone assay. Blood (about $300 \mu \mathrm{l}$ ) was collected from the left ventricle immediately after the specimens had been killed. Samples were centrifuged at $1600 \mathrm{~g}$ and plasma (about $150 \mu \mathrm{l})$ stored at $-20^{\circ} \mathrm{C}$ until assayed.

Testosterone determinations were performed on extracts of plasma using TRK 402 tritiated testosterone (Radiochemical Centre, Amersham, UK), and a highly specific antiserum raised against testosterone-3-carboxymethyloxime-bovine serum albumin (Miller \& Kewley, 1976; Lindeque et al., 1986). Cross-reaction with all major naturally occurring steroids was $<0.1 \%$ except for dihydrotestosterone for which it was $5.1 \%$. The intra- and interassay coefficients of variation were 3.1 and $8.4 \%$ respectively. Sensitivity was $1.44 \mathrm{ng} / \mathrm{ml}$.

Statistics. Differences between means have been evaluated using the Student's $t$ test when two means are compared, and one-way analyses of variance when more than two means are compared. Data are presented as mean \pm 1 s.d.

\section{Results}

\section{Spermatogenic cycle}

During winter and early summer (June to January) the testes were spermatogenically inactive and the seminiferous epithelium comprised a single layer of spermatogonia and Sertoli cells (Fig. 1a). The apical regions of the Sertoli cells contained large storage droplets resulting from the phagocytosis of residual bodies formed during spermiation (Fig. 1a). Spermatogenesis started in February and by late March the seminiferous epithelium was 5-6 cells thick (Fig. 1b). Spermiogenesis began in April (Fig. 1c), spermatozoa were released to the epididymides (Fig. 1d) in late April and copulation (indicated by the presence of spermatozoa in the female reproductive tract) occurred in late April and May. This pattern of seasonal spermatogenic activity was mirrored by

Fig. 4. Electron micrographs of Leydig cells from specimens collected during spermiogenesis (late April) showing the absence of the very large lipid droplets, and the abundant SER, Golgi bodies (G), and mitochondria (M). A few lysosomes (L) and peroxisomes (P) are present (c) and rarely the peroxisomes have a crystalline core (a, insert). Scale bars $=2 \mu \mathrm{m}(\mathrm{a}) ; 0.5 \mu \mathrm{m}(\mathrm{b}$, c); $0 \cdot 2 \mu \mathrm{m}$ (a inset). 


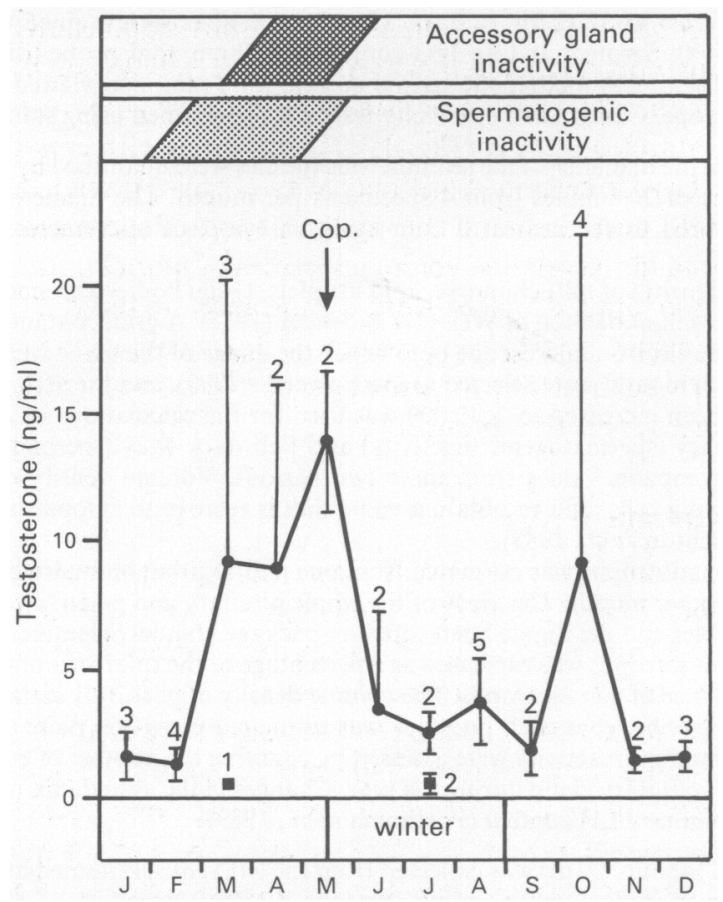

Fig. 5. Plasma testosterone concentrations and a summary of the reproductive cycle of male Schreibers' long-fingered bat. Shaded areas indicate periods of accessory gland and spermatogenic activity. Plasma testosterone concentrations of adult bats $(\boldsymbol{\theta})$ and juveniles $(\boldsymbol{\square})$ are given as mean \pm 1 s.d. Sample size is given above each point. Cop. = copulation.

changes in the mass of the testes, and diameter of the seminiferous tubules (Fig. 2) both of which were significantly greater $(P<0.001)$ during late spermatogenesis (March to May) than during spermatogenic inactivity.

Male long-fingered bats attained sexual maturity approximately 14 months after birth and consequently, during winter, the Sertoli cells of juveniles did not possess the large storage droplets that characterized the Sertoli cells of adults.

\section{Accessory gland activity}

The accessory gland complex comprised a urethral gland, a compound prostate, and a bilobed ampullary gland into which the vasa deferentia drained. The mass of the accessory gland complex was low during spermatogenic inactivity $(10.0 \pm 2.0 \mathrm{mg} ; n=36)$ and significantly elevated during spermatogenesis $(34.0 \pm 5.0 \mathrm{mg} ; n=12 ; P<0.001 ;$ Fig. 2). All three components of the accessory complex were secretorily active during spermatogenesis (March-May) and inactive during the remainder of the year (Figs le \& f).

\section{Leydig cell activity}

During spermatogenesis, the Leydig cells were large with numerous mitochondria, lipid droplets and Golgi bodies, and a few peroxisomes (Table 1, Figs $3 \&$ 4). Smooth endoplasmic reticulum, which was arranged as a meshwork of anastomosing tubules of varied diameter (Figs $3 \& 4$ ), was abundant, and rough endoplasmic reticulum was rare. The diameter of the lipid droplets was greatest in February $(4.3 \pm 1.6 \mu \mathrm{m} ; n=35,4$ bats) and thereafter decreased to March 
$(1.8 \pm 0.12 \mu \mathrm{m} ; n=31,3$ bats) when the diameter was not significantly different from that in specimens collected during reproductive activity (August, $1.2 \pm 0.06 \mu \mathrm{m} ; n=28,3$ bats; $P>0.05$ ). Mitochondria had predominantly lamellar cristae in February (Fig. 3b), and both tubular and lamellar cristae between March and May (Fig. 4c). Peroxisomes with crystalline cores were present in the cytoplasm of the Leydig cells in April and May (Fig. 4, insert). From May onwards the diameter of the Leydig cells decreased and during the period of spermatogenic inactivity the cells were significantly smaller, and the relative volume densities of mitochondria, Golgi bodies, smooth endoplasmic reticulum and lipid droplets were significantly reduced (Table 1). Multivesicular bodies, lysosomes, and myelin figures were common during reproductive inactivity, the mitochondria had lamellar cristae, and the organization of the smooth endoplasmic reticulum was similar to that of reproductively active animals.

\section{Plasma testosterone concentrations (Fig. 5)}

Plasma testosterone concentrations were low during spermatogenic inactivity (JuneSeptember, and November-February; $2 \cdot 17 \pm 1 \cdot 60 \mathrm{ng} / \mathrm{ml} ; n=23$ ) although higher than that of juvenile males $(0.48 \pm 0.29 \mathrm{ng} / \mathrm{ml} ; n=3)$. Testosterone concentrations were elevated during spermatogenesis, and in October, in reproductively inactive specimens. Both peaks were recorded in 1986 and 1987, and the maximum plasma testosterone concentration in October $(27.0 \mathrm{ng} / \mathrm{ml})$ was greater than the maximum recorded during spermatogenesis $(22.3 \mathrm{ng} / \mathrm{ml})$. Plasma testosterone concentrations in specimens at similar stages of spermatogenesis varied (early spermiogenesis, $2 \cdot 51-22 \cdot 30 \mathrm{ng} / \mathrm{ml}$; late spermiogenesis, $4.76-15 \cdot 83 \mathrm{ng} / \mathrm{ml}$ ). The Leydig cells from specimens with low plasma testosterone concentrations were slightly smaller $(P>0 \cdot 1)$, but the relative volume densities of mitochondria, lipid droplets, Golgi bodies and smooth endoplasmic reticulum were not different from those of specimens with elevated plasma testosterone concentrations. The Leydig cells of specimens from October with high plasma testosterone concentrations did not differ significantly in size or abundance of organelles from those of specimens collected at other times during reproductive inactivity $(P>0.05)$.

\section{Activity of LH gonadotrophs}

The percentage of the area of the pars distalis that was occupied by LH gonadotrophs was relatively low during reproductive inactivity (Fig. 6a; October, 10.4\%), increased before spermatogenesis (December, 13.4\%), reached a peak during spermatogenesis (Fig. 6b; March, 19.4\%) and decreased in late spermatogenesis (May, 10.7\%). Although the weight of the pituitary gland fluctuated from $0.8 \mathrm{mg}$ in December to $1.25 \mathrm{mg}$ in May (Fig. 7a), there was no significant correlation between pituitary weight and abundance of LH gonadotrophs (Pearson's correlation coefficient, $r=0.25$ ). Changes in the weight of the pituitary did not reflect changes in the size of the bats; forearm length did not change significantly during the year $(P<0 \cdot 05 ;$ Fig. 7a).

During reproductive inactivity the volume density of labelled secretory granules in the $\mathbf{L H}$ gonadotrophs and the pituitary LH content were low (Figs 6c \& 7b). Both increased during early spermatogenesis, reaching peaks in March/April (Figs 6d \& 7b) which were significantly greater than the levels during reproductive inactivity $(P<0.05)$. From April onwards (late spermatogenesis) both the volume density of granules and pituitary LH content decreased to their winter levels (Fig. 7b). There was a marked increase in the number of secretory granules in October but there was no parallel change in LH content (Fig. 7b).

\section{Discussion}

The pattern of reproduction in male long-fingered bats is relatively inflexible and at all latitudes spermatogenesis is seasonal, lasting from 2.5 to about 5 months (Baker \& Bird, 1936; Dwyer, 1963, 

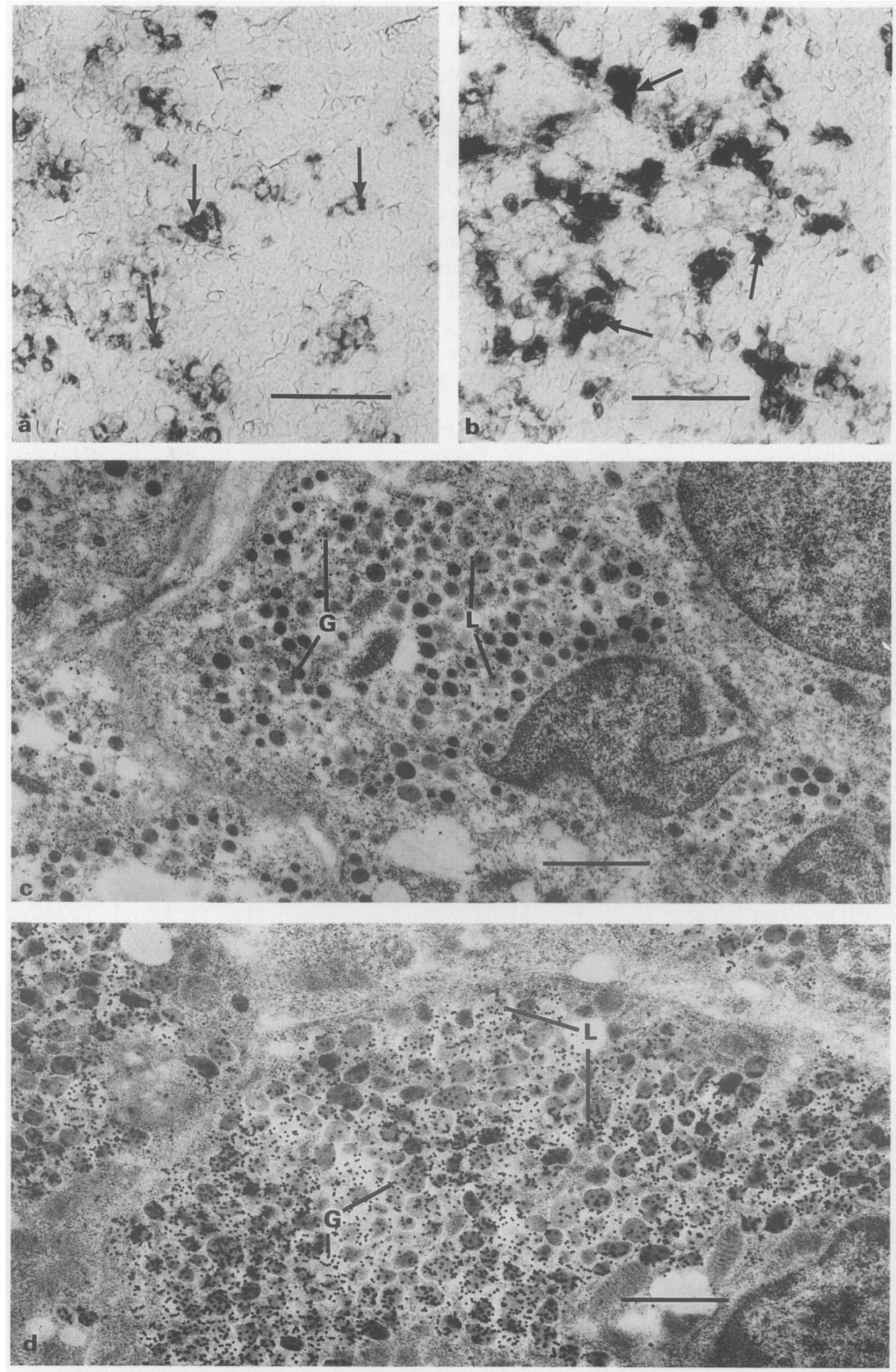
1968; Medway, 1971; Richardson, 1977; Brosset \& Saint Girons, 1980; van der Merwe, 1986; McWilliam, 1988; present study). Spermiation occurs just before copulation, after which the testes regress rapidly and are spermatogenically inactive for the rest of the year (McWilliam, 1988, for review). The variation in duration of spermatogenesis does not have a latitudinal basis and the length of spermatogenesis in tropical and temperate latitudes is similar (Courrier, 1927; Medway, 1971; Richardson, 1977; McWilliam, 1988; present study).

Since spermatogenesis occurs in the months before copulation, the timing of spermatogenesis will be influenced principally by the timing of the female reproductive cycle, which is probably controlled by nutritional requirements during lactation (Bronson, 1985, for review; McWilliam, 1988). Consequently, latitudinally related changes in the timing of ovulation are paralleled by changes in the initiation of spermatogenesis (McWilliam, 1988). The only exception is in Australia $\left(\sim 28^{\circ} \mathrm{S}\right.$ ) where ovulation in $M$. australis occurs about 2 months later than in $M$. schreibersii although spermatogenesis is initiated at the same time in both (Richardson, 1977). The delay in ovulation is accommodated by a protraction of spermatogenesis and a 1-month period of sperm storage in male $M$. australis.

An increase in the size of Leydig cells, and in the abundance of SER, mitochondria and Golgi bodies, combined with a decrease in the abundance and size of lipid droplets, are correlates of increased steroidogenesis in mammalian Leydig cells (Zirkin et al., 1980; Hall, 1984; Lunstra et al., 1986; Nistal et al., 1986). Similar changes in size and ultrastructure of the Leydig cells of bats have been described and correlated with changes in reproductive condition and testosterone production (Miller, 1939; Pearson et al., 1952; Krutzsch, 1975; Kayanja \& Mutere, 1978; Gustafson, 1979, 1987; Ohata, 1979; Loh \& Gemmell, 1980; Bernard, 1986; Krutzsch \& Crichton, 1987). In the present study, the increase in size of the Leydig cells and concomitant changes in ultrastructure during spermatogenesis support the occurrence of a period of elevated steroidogenesis at this time. During spermatogenic inactivity the reduced size of the Leydig cells, and the presence of lysosomes, multivesicular bodies and myelin figures indicate that autolysis is occurring and that the rate of steroidogenesis is reduced. There are no comparable data for other long-fingered bats although an equivalent change in size of Leydig cells has been reported for $M$. schreibersii from Australia (Richardson, 1977).

The coincidence of the major peak in plasma testosterone (March-May) with spermatogenesis and activity of the accessory gland complex (present study) is not unexpected since testosterone is typically required for both processes (de Kretser, 1984, for review) and similar patterns have been described for hibernating rhinolophid and vespertilionid bats (Courrier, 1927; Racey, 1974; Racey \& Tam, 1974; Gustafson \& Shemesh, 1976; Krutzsch et al., 1976; Richardson, 1977; Brosset \& Saint Girons, 1980; Beasley et al., 1984; Bernard, 1986). The peak mean plasma testosterone concentration in May $(14 \mathrm{ng} / \mathrm{ml})$ is lower than the maximum concentrations that have been reported during spermatogenesis in other hibernating vespertilionid bats $(102 \mathrm{ng} / \mathrm{ml}$, Nyctalus noctula: Racey, 1974; $60 \mathrm{ng} / \mathrm{ml}$, Myotis lucifugus: Gustafson \& Shemesh, 1976), but falls within the wide range reported for all bats. The extensive variability in plasma testosterone concentrations of longfingered bats in the same reproductive condition has not previously been highlighted. However, in the majority of mammals the secretion of luteinizing hormone, and consequently testosterone, is episodic (de Kretser, 1984; Turek \& van Cauter, 1988, for reviews), and the variation of plasma testosterone concentrations in the long-fingered bat may be a reflection of this.

Fig. 6. Light and electron micrographs of immunogold stained sections of the anterior pituitary. Note the marked differences in the abundance of LH gonadotrophs (arrows) $(\mathbf{a}, \mathbf{b})$ and in the abundance of $\mathrm{LH}$ immunoreactive granules $(\mathrm{G})$ and the amount of label $(\mathrm{L})(\mathrm{c}, \mathrm{d})$ during reproductive inactivity $(\mathrm{a}, \mathrm{c})$ and during spermatogenesis $(\mathrm{b}, \mathrm{d})$. Scale bars $=50 \mu \mathrm{m}(\mathrm{a}, \mathrm{b}) ; 1 \mu \mathrm{m}$ (c, d). 


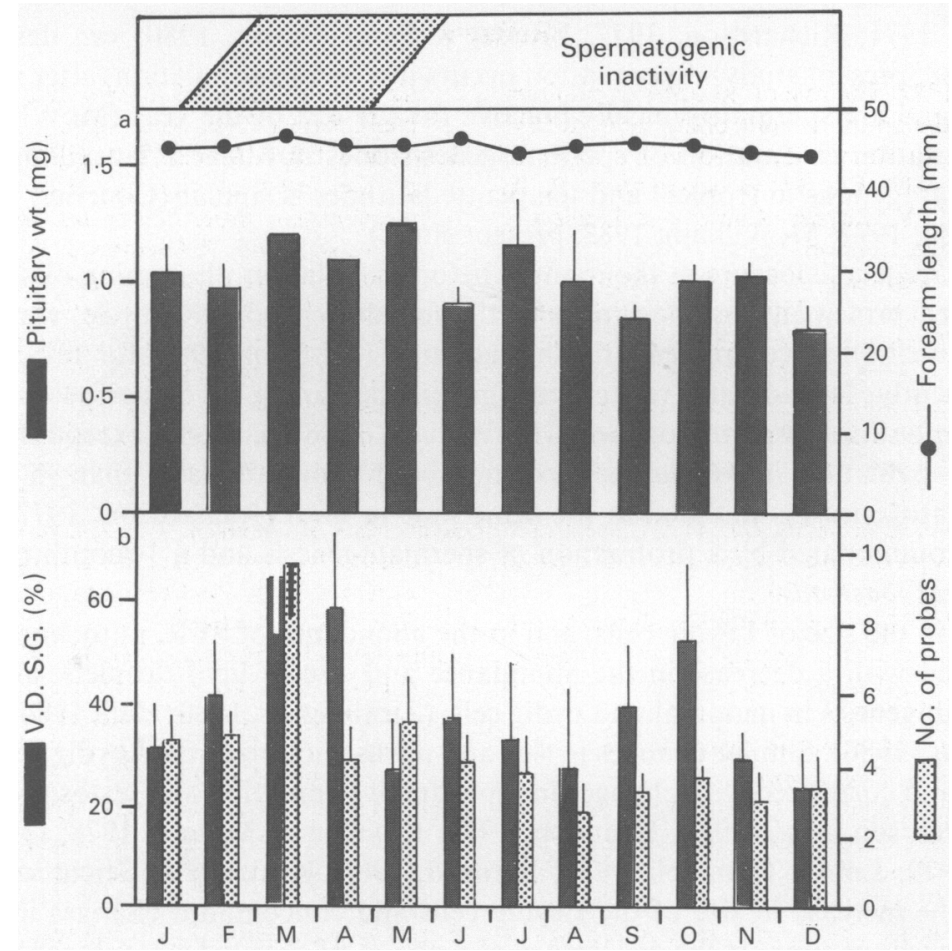

Fig. 7. Monthly changes in forearm length and mass of the pituitary (a), and pituitary LH content (b). Sample size for forearm length and pituitary mass is 3-4 per month and standard deviations where not shown are too small to illustrate. Pituitary LH content is illustrated in terms of the volume density of secretory granules (V.D. S.G.) and the number of gold probes per granule. Values are means \pm 1 s.d. for 10 gonadotrophs from 1 bat per month. Shaded area represents the period of spermatogenesis.

The increase in plasma testosterone concentrations in October is unique and intriguing, but its biological significance is difficult to interpret since it occurs in the absence of any reproductive activity. It is unlikely to be an artefact since it was recorded in 2 consecutive years, and coincides with increased activity of the gonadotrophs. It is probably short-lived since it was not recorded in all the specimens from October and this may explain the absence of previous reports of this phenomenon.

In spite of the small sample size, the results from the present study indicate that gonadotroph activity begins in December/January, possibly in response to decreasing daylength following the summer solstice, and coincides with increasing plasma testosterone concentrations and spermatogenesis. The $50 \%$ decrease in pituitary $\mathrm{LH}$ content from March to April probably reflects an increased rate of secretion which coincides with spermiogenesis and peak plasma testosterone concentrations. A similar decrease in LH- $\beta$ immunoreactivity occurs in male litle brown bats (Myotis lucifugus) towards the end of spermatogenesis (Anthony \& Gustafson, 1984; Anthony, 1987).

We thank Dr Alan Hodgson for critically reading a draft of this manuscript; Joy Paton, Vanessa Jones and the Staff of the Rhodes University Electron Microscopy Unit for technical help; and Rhodes University, the FRD, the MRC, and the University of Cape Town for financial assistance. 


\section{References}

Anthony, E.L.P. (1987) The role of the anterior pituitary and the hypothalamus in controlling reproductive cycles in bats. In Recent Advances in the Study of Bats, pp. 421-439. Eds M. Brock-Fenton, P. A. Racey \& J. M. V. Rayner. Cambridge University Press, Cambridge, London.

Anthony, E.L.P. \& Gustafson, A.W. (1984) Seasonal variation in pituitary LH-gonadotropes of the hibernating bat Myotis lucifugus lucifugus: an immunohistochemical study. Am. J. Anat. 170, 101-115.

Baker, J.R. \& Bird, T.F. (1936) The seasons in a tropical rain-forest (New Hebrides): Part 4. Insectivorous bats (Vespertilionidae and Rhinolophidae). J. Linn. Soc. (Zool.) 40, 143-161.

Beasley, L.J., Smale, L. \& Smith, E.R. (1984) Melatonin influences the reproductive physiology of male pallid bats. Biol. Reprod. 30, 300-305.

Bernard, R.T.F. (1986) Seasonal changes in plasma testosterone concentrations and Leydig cell and accessory gland activity in the Cape horseshoe bat (Rhinolophus capensis). J. Reprod. Fert. 78, 413-422.

Bronson, F.H. (1985) Mammalian reproduction: an ecological perspective. Biol. Reprod. 32, 1-26.

Brosset, A. \& Saint-Girons, H. (1980) Cycles de reproduction des Microchiropteres troglophiles du nordest du Gabon. Mammalia 44, 225-232.

Courrier, R. (1927) Etude sur le déterminism des caractères sexuels secondaires chez quelques mammifères á activité testiculaire périodique. Archs Biol. 37, 173-334.

Crichton, E.G., Seamark, R.F. \& Krutzsch, P.H. (1989) The status of the corpus luteum during pregnancy in Miniopterus schreibersii (Chiroptera: Vespertilionidae) with emphasis on its role in developmental delay. Cell Tissue Res. 258, 183-201.

Cross, R.H.M. (1989) A reliable epoxy resin mixture and its application in routine biological transmission electron microscopy. Micron and Microscopica Acta 20, 1-7.

de Kretser, D.M. (1984) The testis. In Reproduction in Mammals, Vol. 3, pp. 76-90. Eds C. R. Austin \& R. V. Short. Cambridge University Press, Cambridge.

Dwyer, P.D. (1963) The breeding biology of Miniopterus schreibersii blepotis (Temminck) (Chiroptera) in northeastern New South Wales. Aust. J. Zool. 11, 219-240.

Dwyer, P.D. (1968) The biology, origin and adaptation of Miniopterus australis (Chiroptera) in New South Wales. Aust. J. Zool. 16, 49-68.

Gustafson, A.W. (1979) Male reproductive patterns in hibernating bats. J. Reprod. Fert. 56, 317-331.

Gustafson, A.W. (1987) Changes in Leydig cell activity during the annual testicular cycle of the bat Myotis lucifugus lucifugus: histology and lipid histochemistry. Am. J. Anat. 178, 312-325.

Gustafson, A.W. \& Shemesh, M. (1976) Changes in plasma testosterone levels during the annual reproductive cycle of the hibernating bat Myotis lucifugus lucifugus with a survey of plasma testosterone levels in adult male vertebrates. Biol. Reprod. 15, 9-24.

Hall, P.F. (1984) Cellular organization for steroidogenesis. Int. Rev. Cytol. 86, 53-94.

Hall, P.F. (1988) Testicular steroid synthesis: Organization and regulation. In The Physiology of Repro- duction, Vol. 1, pp. 975-998. Eds E. Knobil \& J. D. Neill. Raven Press, New York.

Kayanja, F.I.B. \& Mutere, F.A. (1978) The fine structure of the testis of the insectivorous bat, Otomops martiensseni. Proc. Fourth Int. Bat Res. Confr. pp. 245-254. Eds R. J. Olembo, J. B. Castelino \& F. A. Mutere. Kenya Literature Bureau, Nairobi.

Krutzsch, P.H. (1975) Reproduction of the Canyon bat, Pipistrellus hesperus, in Southwestern United States. Am. J. Anat. 143, 163-200.

Krutzsch, P.H. \& Crichton, E.G. (1987) Reproductive biology of the male little Mastiff bat, Mormopterus planiceps (Chiroptera: Molossidae), in Southeast Australia. Am. J. Anat. 178, 352-368.

Krutzsch, P.H., Watson, R.H. \& Lox, C.D. (1976) Reproductive biology of the male leaf-nosed bat, Macrotus waterhousii in Southwestern United States. Anat. Rec. 184, 611-636.

Lindeque, M., Skinner, J.D. \& Millar, R.P. (1986) Adrenal and gonadal contribution to circulating androgens in spotted hyaenas (Crocuta crocuta) as revealed by LHRH, hCG and ACTH stimulation. $J$. Reprod. Fert. 78, 21 I-217.

Loh, H.S.F. \& Gemmell, R.T. (1980) Changes in the fine structure of the testicular Leydig cells of the seasonally-breeding bat Myotis adversus. Cell Tissue Res. 210, 339-347.

Lunstra, D.D., Ford, J.J., Christenson, R.K. \& Allrich, R.D. (1986) Changes in Leydig cell ultrastructure and function during pubertal development in the boar. Biol. Reprod. 34, 145-158.

McWilliam, A.N. (1988) The reproductive cycle of male long-fingered bats, Miniopterus minor (Chiroptera: Vespertilionidae), in a seasonal environment of the African tropics. J. Zool., Lond. 216, 119-129.

Medway, Lord (1971) Observations of social and reproductive biology of the bent-winged bat Miniopterus australis in northern Borneo. J. Zool., Lond. 165, 261-273.

Millar, R.P. \& Kewley, C. (1976) Production of a specific antiserum for testosterone. S. Afr. med. J. 50, 1021-1022.

Miller, R.E. (1939) The reproductive cycle in male bats of the species Myotis lucifugus lucifugus and Myotis grisescens. J. Morph. 64, 267-295.

Nistal, M., Paniagua, R., Regadera, J., Santamaria, L. \& Amat, P. (1986) A quantitative morphological study of human Leydig cells from birth to adulthood. Cell Tissue Res. 246, 229-236.

Ohata, M. (1979) Electron microscope study on the bat testicular interstitial cell with special reference to the cytoplasmic crystalloid, Arch. histol. jap. 42, 103-118.

Pearson, O.P., Koford, M.R. \& Pearson, A.K. (1952) Reproduction of the lump-nosed bat (Corynorhinus rafinesquei) in California. J. Mammal. 33, 273-320.

Posthuma, G., Slot, J.W. \& Geuze, H.J. (1987) Usefulness of the immunogold technique in quantitation of a soluble protein in ultra-thin sections. J. Histochem. Cytochem. 35, 405-410.

Racey, P.A. (1974) The reproductive cycle in male noctule bats Nyctalus noctula. J. Reprod. Fert. 41, 169-182. 
Racey, P.A. (1982) Ecology of bat reproduction. In Ecology of Bats, pp. 57-104. Ed. T. H. Kunz. Plenum Press, New York.

Racey, P.A. \& Tam, W.H. (1974) Reproduction in male Pipistrellus pipistrellus (Mammalia: Chiroptera). $J$. Zool., Lond. 172, 101-122.

Richardson, E.G. (1977) The biology and evolution of the reproductive cycle of Miniopterus schreibersii and Miniopterus australis (Chiroptera: Vespertilionidae). J. Zool., Lond. 183, 353-375.

Turek, F.W. \& van Cauter, E.V. (1988) Rhythms in reproduction. In Physiology of Reproduction, Vol. 2, pp. 1789-1830. Eds E. Knobil \& J. D. Neill. Raven Press, New York.
Van der Merwe, M. (1986) Reproductive strategy of Miniopterus schreibersii natalensis. Cimbebasia 8, 107-111.

Weibel, E.R. \& Bolender, R.P. (1973) Stereological techniques for electron microscopic morphometry. In Principles and Techniques of Electron microscopy, Vol. 3, pp. 237-296. Ed. M. A. Hayat. Van NostrandReinhold, New York.

Zirkin, B.R., Ewing, L.L., Kromann, N. \& Cochran, R.C. (1980) Testosterone secretion by rat, rabbit, guinea pig, dog and hamster testes perfused in vitro: correlation with Leydig cell ultrastructure. Endocrinology 107, 1867-1874.

Received 17 May 1990 